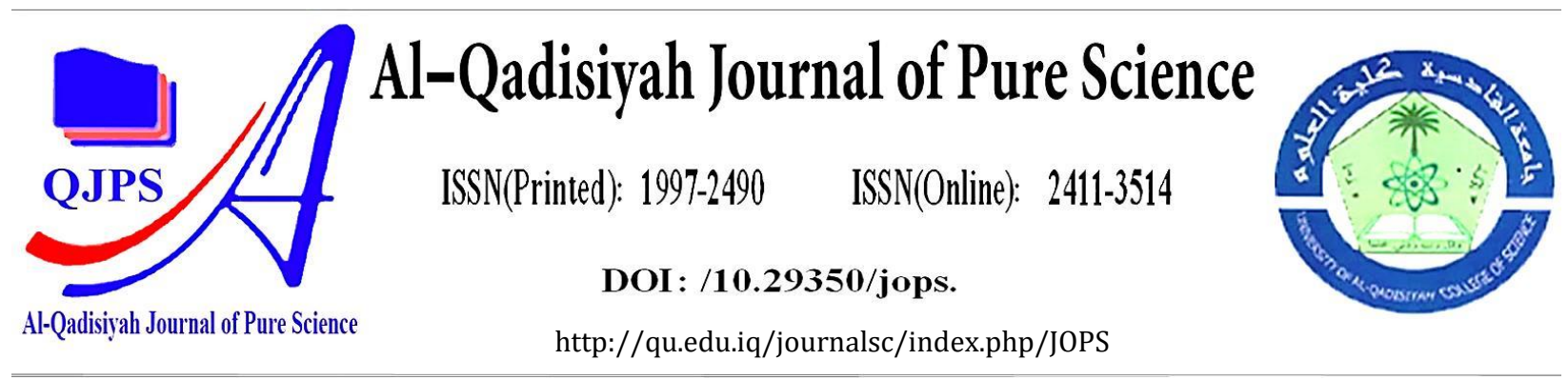

\title{
Anti-Plasmid Activity of Chlorpromazine in Types of Antibiotics Resistant Pathogenic Bacteria
}

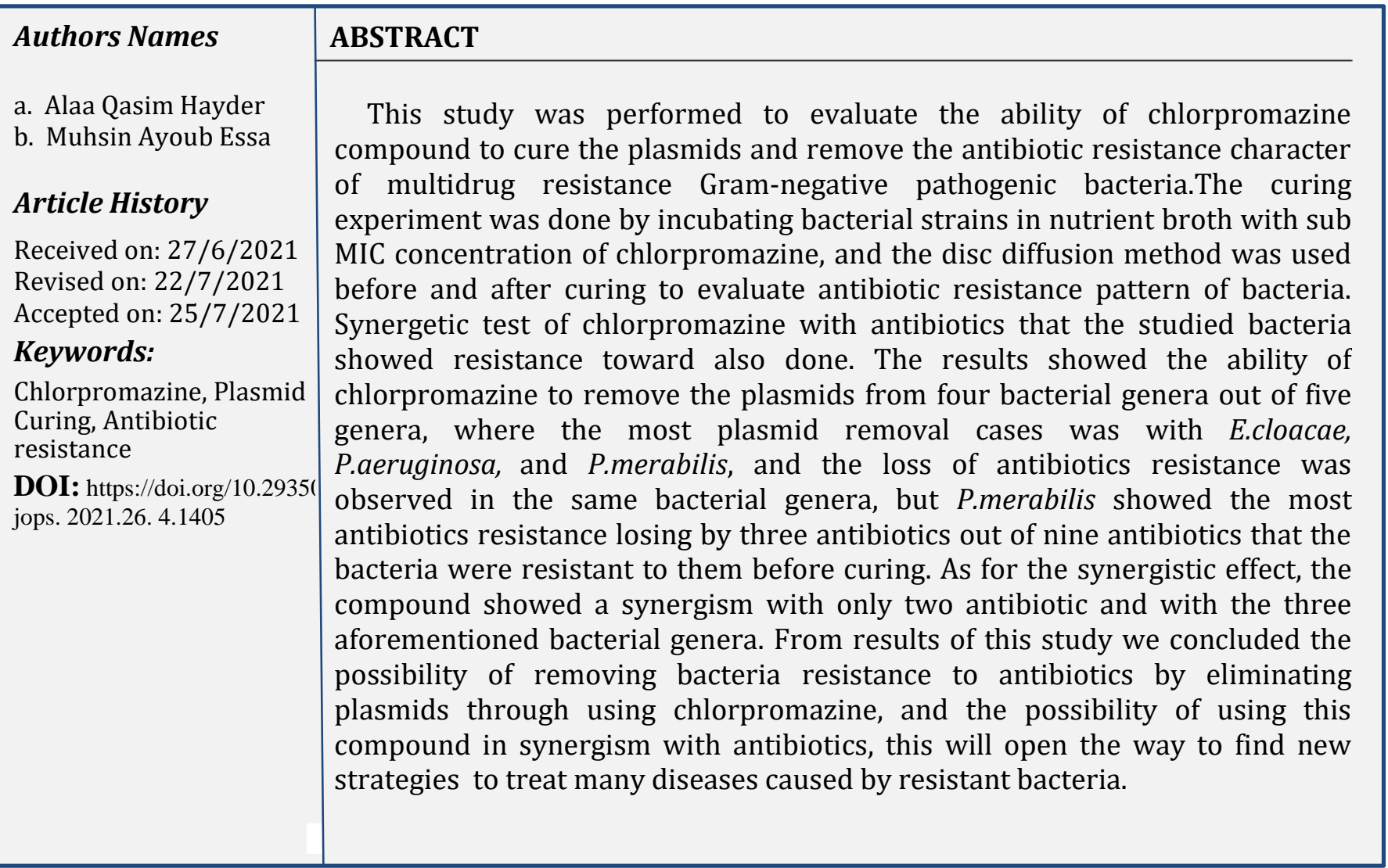

\section{Introduction}

Antibiotics are group of compounds that are naturally produced by different organisms and have either lethal or inhibitory action against other organisms [1]. The era of antibiotics and their use in medicine began with the discovery of penicillin at 1941. This was considered one of the most important medical achievements. However, the scientist Alexander Fleming who discovered penicillin predicted at the same time the existence of microbes adapted to resist it, and the Center for Disease Control (CDC) confirmed that resistance to penicillin by bacteria has arisen just one year after its discovery [6]. Increasing the consumption of antibiotics always leads to the emergence and proliferation of resistant bacteria [12]. As the bacteria acquire resistance to antibiotics either through chromosomal mutations or through horizontal gene transfer by mobile genetic elements including plasmids, resistant or Rplasmids in particular [19]. According to World Health Organization (WHO) the development and spread of 
antibiotic-resistant bacteria are one of the main problems facing the world in our time, and its danger is evident in the difficulty or failure to treat even minor diseases. Moreover, it could increase treatment cost, hospitalization time, economic and social effects [5].

The ability of bacteria to match available drugs and their ability to develop various resistant mechanisms continuously calls us to line with this development through developing current antibiotics, or search for alternatives [16]. One solution proposes is to eliminate the problem of resistance by removing the antimicrobial resistance genes (ARGs). These genes usually carried on the plasmid, so since 1971 the concept of (curing) has been associated with plasmids [7]. "Curing" defined as the removing or deleting plasmids from bacterial cells by treating them with specific physical, chemical, or biological factors which are called "curing agents" [8]. Plasmid curing might convert the antibioticresistant bacteria into sensitive bacteria, thus facilitating their treatment [9].

Curing agents could be used for several purposes. For example, they can be given to patients before surgery in order to reduce the possibility of nosocomial infections caused by multidrug-resistant bacteria, Furthermore, given to travelers heading to different countries, in wastewater treatment systems by adding them to the water before being released to the environment. Finally these materials may be added to waste before using it as fertilizers. All of this aims to remove the resistance genes, thus limit the global spread of multidrug-resistant bacteria in attempt to put an end to this dangerous phenomena [20].

Chlorpromazine CPZ was discovered in 1953 by Paul Charpentier at the Rhone-Poulenc laboratory in Paris, which was known to possess anxiolytic and antipsychotic properties in addition to its antihistamine effect [24]. This compound was exploited by psychiatrists in the treatment of mental illness patients, and this resulted in a complete emptying of mental hospitals in Fifties of the Nineteenth century. Therefore, the discovery and use of CPZ represent the beginning of modern psychiatry and psychopharmacology [4]. CPZ antibacterial properties were known immediately after its discovery due to its wide use. But, it was not used as antibiotic because the golden age of antibiotics had just begun at that time. So, there was not need to use CPZ or its derivatives. It was also noted that long term use of CPZ results in severe side effects like skin pigmentation, visual impairment, and functional disturbance of certain organs. However, with the antibiotic-resistance era it is required to find alternatives and CPZ may be one of them [11].

The current study aims to evaluate the ability of chlorpromazine to remove plasmids from a group of multidrug-resistant Gram-negative bacteria, and the possibility of converting these isolates from resistant to sensitive against a group of common antibiotics.

\section{Materials and methods} Bacterial isolates:

Five bacterial isolates(Escherichia coli, Proteus mirabilis, Klebsiiella pneumonia , Enterobacter cloacae and Pseudomonas aeruginosa) were used in this study. These bacteria were isolated and diagnosed in Biology Department/Science College/Mosul University and were selected depending on their high resistant to antibiotics, their diagnosis was confirmed by using API 20.

\section{Antibiotics:}

Twelve antibiotics used in this study were supplied by Bioanalyse/Turkish and shown in Table (1).

\section{Chlorpromazine (CPZ):}

Chlorpromazine(Egyptian Pharmaceutical Company), it's common name is Neurazine, was obtained from the local market of Mosul city. 
Table1 Antibiotic discs used in this study

\begin{tabular}{|c|c|c|}
\hline Antibiotic names & Symbol & Concentration $(\boldsymbol{\mu g})$ \\
\hline Ampicillin & AM & 10 \\
\hline Ceftriaxone & CRO & 10 \\
\hline Cefotaxime & CTX & 30 \\
\hline Ciprofloxacine & CIP & 5 \\
\hline Levofloxacine & LEV & 5 \\
\hline Novobiocin & NV & 30 \\
\hline Ofloxacin & OFX & 5 \\
\hline Penicillin & P & 10 \\
\hline Tetracyclin & TE & 10 \\
\hline Trimethoprim-Sulphamethoxazol & SXT & $1.25 / 23.75$ \\
\hline Trimethoprime & TMP & 10 \\
\hline Vancomycin & VA & 30 \\
\hline & &
\end{tabular}

\section{Antibiotic sensitivity test:}

The sensitivity of bacteria to antibiotics was tested using disc diffusion method described by Kirby \& Bauer 1966, by using the antibiotic discs shown in Table (1) and MuellerHinton agar. Following the recommendations of Clinical and Laboratory standard institute CLSI [17].

\section{Synergism test:}

Bacterial Inoculation were prepared by diluting overnight cultures in a sterile normal saline suspension then marched with McFarland turbidity. Bacterial suspension was then plated on Mueller Hinton Agar by using a sterile cotton swab. Antibiotic disks were placed on. Then by using micropipette $10 \mu \mathrm{lof} \mathrm{CPZ}$ dissolved in DMSO at a concentration of 3 $\mathrm{mg} / \mathrm{ml}$ was added on antibiotic disks. The plates were then incubated at $37^{\circ} \mathrm{C}$ for 24 hours and the inhibition zones were measured in millimeters [13].

\section{Plasmids detection:}

plasmid DNA isolated by using the kit supplied by Qiagen/ German. Then DNA gel electrophoresis done to show plasmid DNA bands.

\section{Curing experiment:}

The minimum inhibitory concentration MIC of $\mathrm{CPZ}$ was determined by macro Dilution Method [26]. It was found that the MIC ranged between (4-8) $\mathrm{mg} / \mathrm{ml}$.

The plasmid curing experiment was performed according to the method described by [21] with some modifications. The bacteria were incubated with sub MIC concentration $(3 \mathrm{mg} / \mathrm{ml})$ of CPZ for 24 hours in nutrient broth. After incubation, the plasmid DNA were isolated and electrophoresed again.

\section{Checking antibiotic sensitivity after curing:}

The antibiotic sensitivity test was performed again after curing by using disc diffusion method also.

\section{Results and Discussion}

As shown in Table (2), all bacterial isolates were multidrug resistant (MDR). This term refers to bacteria that are resist to three or more antibiotics belonging to different antibiotic classes. The spread of resistance among pathogenic bacteria considered a very serious health problem. [18]. There are several reasons explains bacterial multidrug-resistance, including exposing the bacteria to antibiotics 
which stimulates chromosomal mutations that may cause converting bacteria from sensitive to resistant. As well as the acquisition of many external resistant genes by horizontal gene transfer, that is mainly happen by R-plasmid, transposons, or viruses. Finally, bacteria possess a tough cell wall and has many peptidoglycan (PG) synthesis and hydrolases enzymes that control bacterial growth and resistant many antibiotics [25].

Table2 Results of antibiotic sensitivity test measured in $\mathrm{mm}$ module

\begin{tabular}{|c|c|c|c|c|c|c|c|c|c|c|c|c|}
\hline \multirow{2}{*}{$\begin{array}{c}\text { Bacterial } \\
\text { Isolates }\end{array}$} & AM & CRO & CTX & CIP & LEV & SXT & VA & TE & NV & P & OFX & TMP \\
\hline E.coli & 0 & 0 & 0 & 32 & 30 & 22 & 0 & 0 & 0 & 0 & 28 & 24 \\
\hline K.pneumoniae & 0 & 0 & 0 & 24 & 20 & 0 & 0 & 0 & 0 & 0 & 16 & 0 \\
\hline P.merabilis & 0 & 0 & 0 & 24 & 24 & 0 & 0 & 0 & 0 & 0 & 16 & 0 \\
\hline E.cloacae & 0 & 0 & 20 & 20 & 26 & 0 & 0 & 0 & 0 & 0 & 20 & 0 \\
\hline P.aeruginosa & 0 & 0 & 0 & 30 & 28 & 0 & 0 & 0 & 0 & 0 & 14 & 0 \\
\hline
\end{tabular}

The synergistic ability of CPZ compound with the antibiotics that the isolates originally were full resistant to them was tested in order to study the possibility of converting these resistance into sensitive. If we take into account that the synergistic effect means increasing in the inhibition zone of antibiotic discs with CPZ in comparison to inhibition zone of antibiotic discs alone. The results shown in table (3) indicate the presence of a synergistic effect ranging between (8-9) $\mathrm{mm}$ for each antibiotics Vancomycin and Tetracyclin with CPZ against each of E.cloacae, P.aeruginosa, and P.merabilis bacteria.

The synergistic effect may be related to the inhibition activity of CPZ against efflux pumps, as these pumps are responsible for multidrug-resistance of bacteria, so by disrupting the activity of these structures the antibiotic molecules can reach their targets at aright concentrations and thus the bacteria become sensitive to them. Endopeptidase (PG hydrolase enzyme) also play a key role in resisting Vancomycin by modifying D-Alanine in the stem peptide [3]. May be due to increase the permeability of cell membranes because of CPZ influences that is results in easier penetration and transit of the antibiotic molecules or due to the removal of the plasmid encoding for resistance [14].

Table3 Results of synergism between CPZ \& antibiotics

\begin{tabular}{|c|c|c|}
\hline \multirow{2}{*}{ Bacterial isolates } & $\begin{array}{c}\text { Antibiotics which show Synergistic effect } \\
\text { with chlorpromazine }\end{array}$ \\
\cline { 2 - 3 } & TE & VA \\
\hline E.cloacae & 0 & 8 \\
\hline P.aeruginosa & 9 & 0 \\
\hline P.merabilis & 0 & 8 \\
\hline E.coli & 0 & 0 \\
\hline K.pneumoniae & 0 & 0 \\
\hline
\end{tabular}

Plasmid content of the five studied bacterial isolates had shown in figure (1-a), where each number represents a bacterial isolate (Starts with 1 and ends with 5). The isolates of Proteus mirabilis (1) and Escherichia coli (5) showed two plasmid bands for each. Whereas, Enterobacter cloacae (2) and Pseudomonas aeruginosa (3) possessed three Plasmid bands for each. Finally, Klebsiiella pneumonia (4) have just one large plasmid band. Sizes of plasmids ranged between $(2,500$ to more than 10,000$)$ 
base pair. Because, the studied bacteria was pathogenic, it's expected to have high plasmid content with different types, this is according to their pathogenicity and their high virulence.

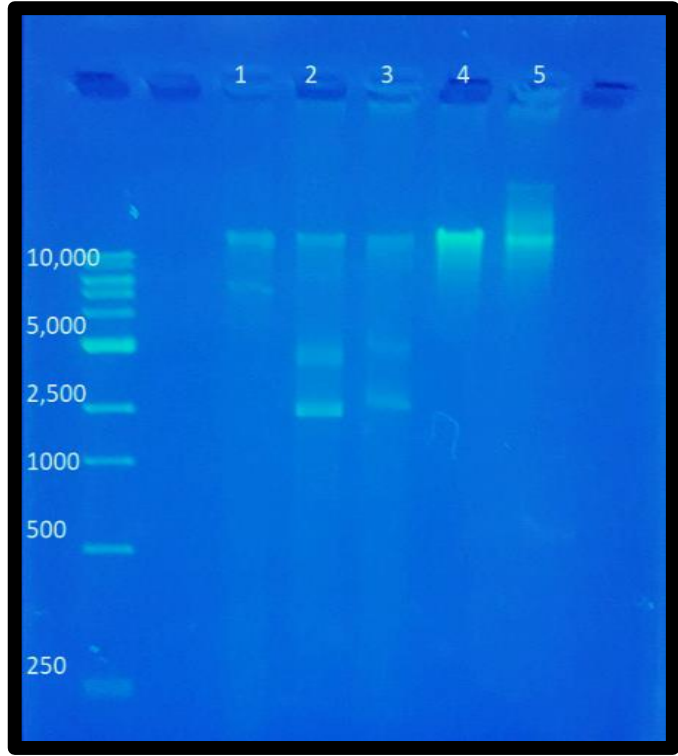

1-a

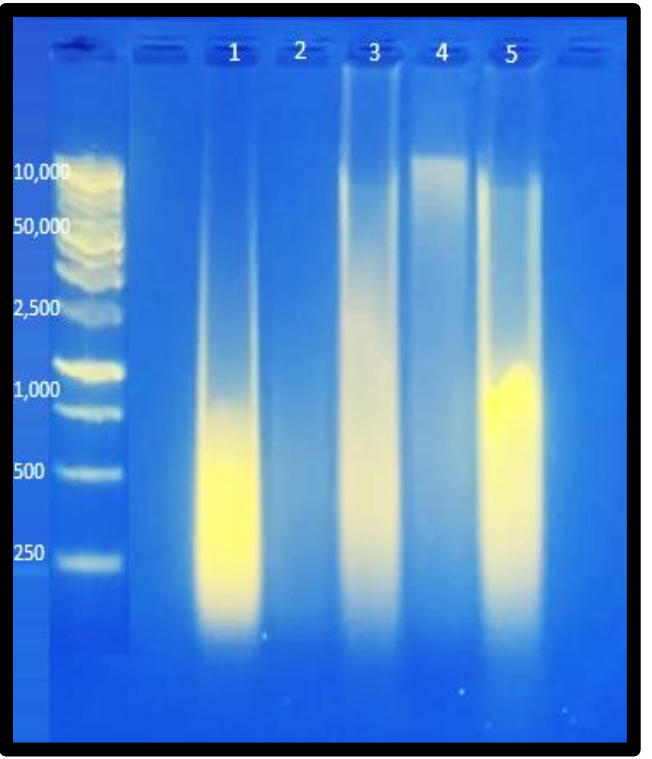

1-b

Figure. 1: (a , b) DNA Gel electrophoresis shows plasmid content of bacterial isolates, where each number represent an isolate \{P.mirabilis(1), E.cloacae(2), P.aeruginosa(3), K.pneumoniae(4), E.coli(5)\}. The conditions was: (Agarose concentration: 1.5 percent; voltage: 80 volt; time: 1 hour). Figure (1-a) shows plasmid content of above-mentioned bacterial isolates without any treating. Figure (1-b) represent plasmid content of the same bacterial isolates after treating them with sub MIC concentration of Chlorpromazine for 24 hours. There is a clear difference between the two figures in the term of the number of plasmid bands. This difference mainly related to plasmid curing activity of Chlorpromazine. As Chlorpromazine intercalated molecules causes break and damage of the plasmid DNA molecules.

Bacterial cell may contain more than one type of plasmid and these plasmids differ in terms of the number of copies present in each cell. A specific plasmid may have two or more copies (up to Hundreds of copies). Other plasmids species may have just one copy per cell. the sizes of plasmids also differ. They are generally range from several thousand to hundreds of thousands of double nitrogen bases [23]. This is explains why the bacterial isolates under study contain different plasmid types in terms of number and sizes.

The plasmid curing experiment was carried out using sub MIC concentration of CPZ, which is showed an excellent efficacy in removing the plasmid content of bacterial cells. Table (4) shows the results of curing and numbers of plasmids before and after curing. And the figure (1-b) shows the plasmid content of the five isolates after the curing experiment. The isolates of P.mirabilis(1), E.cloacae(2), and P.aeruginosa(3) were lost all of their plasmid content. E.coli(5) lost one plasmid out of two. While, $K$.pneumoniae(4) had retained its plasmid content. The smear appeared in the figure (1-b) represent a lysed DNA

Phenothiazine compounds including CPZ possesses anti-bacterial activity and this activity may be direct through several mechanisms such as inhibiting important enzymes or cell lyses, or indirect that are represented in converting resistant bacteria to sensitive one. One mechanisms used under this property is the removal of R-plasmids. This happens when A special complex formation was found with the covalently closed circular form of plasmid DNA. G-C rich regions of plasmid have higher affinity for 
phenothiazine molecules than A-T rich regions. Because of the G-C rich regions have a three hydrogen bonds, it was supposed that these regions could have a key role in the plasmid stability and replication. Plasmid DNA becomes more rigid due to the intercalated phenothiazine molecules and strand breaks occur that lead to the formation of non-replicative forms, open, circular or linear derivatives form. It is known that open circular forms or linear forms of plasmid cannot start to replicate from the origin of promoter region due to the relaxed form of plasmid DNA.

The plasmid also may be removed by inhibiting the conjugation process and plasmid transmission. This is occur when conjugation sex pili formation inhibited by CPZ molecules. It is important to know that the removal process are not limited to R-plasmids only, but also includes other types of plasmids $[15][2]$.

Table4 Plasmid content before and after curing experiment

\begin{tabular}{|c|c|c|}
\hline Bacterial strains & $\begin{array}{c}\text { Number of plasmids } \\
\text { before curing }\end{array}$ & $\begin{array}{c}\text { Number of plasmids } \\
\text { after curing }\end{array}$ \\
\hline E.cloacae & 3 & 0 \\
\hline P.aeruginosa & 3 & 0 \\
\hline P.merabilis & 2 & 0 \\
\hline E.coli & 2 & 1 \\
\hline K.pneumoniae & 1 & 1 \\
\hline
\end{tabular}

After curing examination an antibiotics sensitivity test, was carried out by previously described discs diffusion method, in order to determine the relationship between plasmids removing and antibiotics resistance activity of the bacterial isolates. The results are shown in Table (5). Both E.coli and K.pneumoniae isolates did not lose any of their antibiotic resistance, while isolates of E.cloacae and P.aeruginosa lost their resistance to Tetracycline and Novobiocin respectively. As each isolate lost its resistance to just one antibiotic, and finally, P.mirabilis was the most affected bacteria, as it lost its resistance to three antibiotics and in a great average which Ceftriaxone, Cefotaxime, and Novobiocin antibiotics. The diameter of inhibition zones were 37, 33, and $20 \mathrm{~mm}$ respectively after being $0 \mathrm{~mm}$ for each of three mentioned antibiotics before plasmid elimination.

Lacking of resistance loss in all of studied bacterial isolates after plasmid curing may be due to the absence of resistance genes on the removed plasmids. Resistance genes may be carried on the bacterial chromosome, so the resistance does not changes with the loss of the plasmids. Removed plasmids may be belonged to types of plasmids other than resistance plasmids. Finally, in some cases resistance may be related to morphological characteristics of bacterial cell which is called a natural resistance. For example the outer membrane of Gram-negative bacteria which contributes in making bacteria resistant to many antibiotics [10] [22]. 
Table5 Antibiotics which become against bacteria plasmid elimination

\begin{tabular}{|c|c|c|c|c|}
\hline \multirow{2}{*}{$\begin{array}{c}\text { Bacterial } \\
\text { strains }\end{array}$} & \multicolumn{4}{|c|}{$\begin{array}{c}\text { Antibiotics which become } \\
\text { effective after plasmid curing }\end{array}$} \\
\cline { 2 - 5 } & TE & NV & CRO & CTX \\
\hline E.cloacae & 14 & 0 & 0 & 0 \\
\hline E.coli & 0 & 0 & 0 & 0 \\
\hline P.aeruginosa & 0 & 15 & 0 & 0 \\
\hline P.merabilis & 0 & 20 & 37 & 33 \\
\hline K.pneumoniae & 0 & 0 & 0 & 0 \\
\hline
\end{tabular}

\section{Conclusions:}

The results of this study indicated the possibility of incorporation of chlorpromazine with antibiotics in order to remove the antibiotic's resistance, as well as reducing the antibiotic's concentration and their side effects. This will opens the way for find a new alternative and safe ways to treat many diseases, but more studies are needed to support this promising therapeutic course. Also chlorpromazine can be used alone or in synergy in vitro in order to eliminate multidrug-resistant bacteria and prevent the spread of resistance.

\section{References:}

[1] Ali, J., Awan, M., Akca, G., Zeb, I., Amin, B. A., Ahmad, R., Shah, M. M., \& Nazir, R. (2020). Prevalence of diversified antibiotic resistant bacteria within sanitation related facilities of human populated workplaces in Abbottabad. PloS one, 15(8), e0233325.

[2] Amaral, L., Kristiansen, J. E., Viveiros, M., \& Atouguia, J. (2001). Activity of phenothiazines against antibioticresistant Mycobacterium tuberculosis: a review supporting further studies that may elucidate the potential use of thioridazine as anti-tuberculosis therapy. Journal of Antimicrobial Chemotherapy, 47(5), 505-511.

[3] Amaral, L., Martins, A., Molnar, J., Kristiansen, J. E., Martins, M., Viveiros, M., Rodrigues, L., Spengler, G., Couto, I., Ramos, J., Dastidar, S., Fanning, S., McCusker, M., \& Pages, J. M. (2010). Phenothiazines, bacterial efflux pumps and targeting the macrophage for enhanced killing of intracellular XDRTB. In vivo (Athens, Greece), 24(4), 409424.

[4] Amaral, L., Viveiros, M., \& Molnar, J. (2004). Antimicrobial activity of phenothiazines. In vivo (Athens, Greece), 18(6), 725-731.

[5] Banu, H., \& Prasad, K. P. (2017). Role of plasmids in microbiology. J Aquac Res Development, 8(466), 2.

[6] Boren, K., Crown, A., \& Carlson, R. (2020). Multidrug and Pan-Antibiotic Resistance-The Role of Antimicrobial and Synergistic Essential Oils: A Review. Natural Product Communications, 15(10), 1934578X20962595.

[7] Bouanchaud, D., Scavizzi, M., and Chabbert, Y. (1968). Elimination by ethidium bromide of antibiotic resistance in enterobacteria and staphylococci. Microbiology, 54(3): 417-425.

[8] Breijyeh, Z., Jubeh, B., \& Karaman, R. (2020). Resistance of Gram-negative bacteria to current antibacterial agents and approaches to resolve it. Molecules, 25(6), 1340.

[9] Canton R, Morosini MI(2011). Emergence and spread of antibiotic resistance following exposure to antibiotics. FEMS Microbiol Rev; 35(5): 977-91.

[10] Carattoli, A. (2013). Plasmids and the spread of resistance. International Journal of Medical Microbiology, 303(67), 298-304. 
[11] DELAY, J., DENIKER, P., \& HARL, J. M. (1952). Traitement des états d'excitation et d'agitation par une méthode médicamenteuse dérivée de l'hibernothérapie [Therapeutic method derived from hiberno-therapy in excitation and agitation states]. Annales medico-psychologiques, 110(2 2), 267-273.

[12] Garner, E., Chen, C., Xia, K., Bowers, J., Engelthaler, D. M., McLain, J., Edwards, M. A., \& Pruden ,A. (2018). Metagenomic characterization of antibiotic resistance genes in full-scale reclaimed water distribution systems and corresponding potable systems. Environmental science \& technology, 52(11), 6113-6125.

[13] Mohammed S; Mahmoud A; Laith M; Najeeb N.(2020) Synergistic Effect of Some Natural Substances in Combination with Antibiotics on MDR Klebsiella isolates, Medico-legal Update, , Vol.20, No. 3

[14] Molnár, J., Földeák, S., Nakamura, M. J., Rausch, H., Domonkos, K., \& Szabó, M. (1992). Antiplasmid activity: loss of bacterial resistance to antibiotics. APMIS. Supplementum, 30, 24-31.

[15] Molnár, J., Mándi, Y., Spengler, G., Haszon, I., Túri, S., Kásler, M., \& Amaral, L. (2014). Synergism between antiplasmid promethazine and antibiotics in vitro and in vivo. BIOCHEMISTRY AND PHARMACOLOGY, 3(4), Azonosító-1000139.

[16] Nagvekar, V., Sawant, S., \& Amey, S. (2020). Prevalence of multidrug-resistant Gram-negative bacteria cases at admission in a multispeciality hospital. Journal of global antimicrobial resistance, 22, 457-461.

[17] National Committee for Clinical Laboratory Standards.. Performance Standards for antimicrobial disk Susceptibility test approved standard.Wayne, PA: NCCLs; 2000.

[18] Oriomah, C., \& Akpe, A. R. (2019). Plasmid curing of antibiotic resistant Escherichia coli isolates from urine and stool samples. Journal of Microbiology and Antimicrobials, 11(1), 1-4.

[19] Ozdemir, K. (2018). CURING THE DRUG RESISTANCE PLASMID IN E. COLI O157: H7. APPLIED ECOLOGY AND ENVIRONMENTAL RESEARCH, 17(6), 14715-14727.

[20] Patwardhan, R. B., Dhakephalkar, P. K., Chopade, B. A., Dhavale, D. D., \& Bhonde, R. R. (2018).Purification and characterization of an active principle, lawsone, responsible for the plasmid curing activity of Plumbago zeylanica root extracts. Frontiers in Microbiology, 9, 2618.

[21] Prestinaci ,F ; Pezzotti ,p and Pantosti, A (2015). Antimicrobial Resistance : a global multifaceted phenomenon . Patho Glob Health 109: (7): 309-318.

[22] Seal, B. S., Drider, D., Oakley, B. B., Brüssow, H., Bikard, D., Rich, J. O., Miller, S., Devillard, E., Kwan, J., \& Bertin, G. (2018). Microbial-derived products as potential new antimicrobials. Veterinary research, 49(1), 1-12.

[23] Snyder, L., Champness, W., \& Champness, W. (1997). Molecular genetics of bacteria (Vol. 19). Washington, DC: Asm Press.

[24] Varga, B., Csonka, Á., Csonka, A., Molnár, J., Amaral, L., \& Spengler, G. (2017). Possible Biological and Clinical Applications of Phenothiazines. Anticancer research, 37(11), 5983-5993.

[25] Vrancianu, C. O., Popa, L. I., Bleotu, C., \& Chifiriuc, M. C. (2020). Targeting plasmids to limit acquisition and transmission of antimicrobial resistance. Frontiers in Microbiology, 11 .

[26] Wiegand, I., Hilpert, K., \& Hancock, R. E. (2008). Agar and broth dilution methods to determine the minimal inhibitory concentration (MIC) of antimicrobial substances. Nature protocols, 3(2), 163-175. 